\title{
HUBUNGAN MOTIVASI BELAJAR TERHADAP HASIL BELAJAR IPA SISWA KELAS V SDN 231 INPRES KAPUNRENGAN KECAMATAN MANGARABOMBANG KABUPATEN TAKALAR
}

\author{
Irwan Sappe, Ernawati, Irmawanty. \\ Pendidikan Guru Sekolah Dasar, Fakultas Keguruan dan Ilmu Pendidikan \\ Universitas Muhammadiyah Makassar \\ Iqramsyar34@gmail.com
}

\begin{abstract}
ABSTRAK
Jenis penelitian ini adalah penelitian korelasi. Penelitian ini bertujuan untuk mengetahui: Hubungan antara motivasi belajar (X) terhadap hasil belajar IPA (Y). Penelitian ini dilaksanakan di SDN 231 Inpres Kapunrengan kecamatan Mangarabombang kabupaten Takalar tahun ajaran 2016/2017. Populasi dalam penelitian ini adalah seluruh siswa SDN 231 Inpres Kapunrengan yang berjumlah 174 siswa. Sedangkan sampel dalam penelitian ini adalah siswa kelas V sebanyak 30 siswa. Instrumen penelitian yang digunakan untuk memperoleh data tentang motivasi belajar adalah angket atau kuesioner, dan dokumentasi berupa nilai ulangan harian untuk memperoleh data tentang hasil belajar IPA. Angket motivasi belajar 13 item. Hasil penelitian menunjukkan bahwa: Ada hubungan positif dan signifikan antara motivasi belajar terhadap hasil belajar IPA siswa SDN 231 Inpres Kapunrengan kecamatan Mangarabombang kabupaten Takalar, dengan koefisien korelasi sebesar 0,449 dan $\mathrm{p}=0,013$.
\end{abstract}

Kata Kunci: Motivasi Belajar, Hasil Belajar IPA 


\section{PENDAHULUAN}

Peran motivasi belajar siswa adalah salah satu faktor yang sangat penting dalam kehidupan dan dunia pendidikan. Dalam dunia pendidikan, motivasi berperan dalam mencapai keberhasilan serta hasil belajar di sekolah, dimana hasil belajar merupakan indikator dari hasil pencapaian belajar siswa. Tapi kenyataan di lapangan banyak siswa di sejumlah sekolah menunjukkan bahwa terdapat perbedaan motivasi belajar yang diwujudkan oleh siswa di sekolah. Sedangkan yang dimaksud dengan motivasi belajar adalah suatu usaha yang disadari untuk menggerakkan, mengarahkan dan menjaga tingkah laku seseorang agar ia terdorong untuk bertindak melakukan sesuatu sehingga mencapai hasil atau tujuan tertentu.

Hasil belajar adalah suatu hasil nyata yang dicapai oleh siswa dalam usaha menguasai kecakapan jasmani dan rohani di sekolah yang diwujudkan dalam bentuk raport pada setiap semester. Ilmu Pengetahuan Alam (IPA) atau sains merupakan disiplin ilmu yang terdiri dari physical sciences (ilmu fisika) dan life science (ilmu biologi). Siswa adalah komponen masukan dalam sistem pendidikan, yang selanjutnya diproses dalam proses pendidikan, sehingga menjadi manusia yang berkualitas sesuai dengan tujuan pendidikan nasional.

Berdasarkan uraian di atas, adapun rumusan masalah dalam penelitian ini adalah: Apakah ada hubungan antara motivasi belajar terhadap hasil belajar IPA siswa kelas V SDN 231 Kapunrengan Kecamatan Mangarabombang Kabupaten Takalar?. Untuk mengetahui ada/tidaknya hubungan motivasi belajar terhadap hasil belajar IPA siswa kelas V SDN 231 Kapunrengan

Kecamatan Mangarabombang Kabupaten Takalar.

\section{Pengertian Motivasi Belajar}

a. Motivasi

Menurut Dimyati dan Mudjiono (2013: 42) motivasi adalah tenaga yang menggerakkan dan mengarahkan aktivitas seseorang. Rusman (2013: 94) mengatakan bahwa motivasi diartikan sebagai faktor-faktor yang penyebab yang menghubungkan dengan sesuatu dengan perilaku seseorang.

Dimyati dan Mudjiono (2013: 88) menjelaskan jenis-jenis motivasi yaitu motivasi primer dan motivasi sekunder. (1) Motivasi primer adalah motivasi yang didasarkan pada motif dasar. Motif-motif dasar berasal dari segi biologis atau jasmani manusia. (2) Motivasi sekunder atau motivasi sosial digolongkan menjadi keinginan- 
keinginan (i) memperoleh pengalaman baru, (ii) untuk mendapat respon, (iii) memperoleh pengakuan, dan (iv) memperoleh rasa aman. Menurut Mc Cleland menggolongkan menjadi kebutuhan-kebutuhan untuk (i) berprestasi, (ii) memperoleh kasih sayang, dan (iii) memperoleh kekuasaan.

Menurut Sardiman (2006: 89) ada berbagai jenis motivasi, yaitu:

1) Motivasi Intrinsik adalah motif-motif yang aktif atau berfungsinya tidak perlu dirangsang dari luar karena dalam diri setiap individu sudah ada dorongan untuk melakukan sesuatu. Seorang siswa melakukan belajar karena didorong tujuan ingin mendapatkan pengetahuan, nilai dan keterampilan.

2) Motivasi ekstrinsik adalah motifmotif yang aktif dan berfungsinya karena adanya perangsang dari luar. Oleh karena itu motivasi ekstrinsik dapat juga dikatakan sebagai bentuk motivasi yang di dalamnya aktivitas belajar dimulai dan diteruskan berdasarkan dorongan dari luar yang tidak secara mutlak berkaitan dengan aktivitas belajar.

Apabila seseorang telah memiliki ciri-ciri motivasi di atas maka orang tersebut selalu memiliki motivasi yang cukup kuat. Dalam kegiatan belajar mengajar akan berhasil baik, kalau siswa tekun mengerjakan tugas, ulet dalam memecahkan berbagai masalah dan hambatan secara mandiri. Selain itu siswa juga harus peka dan responsif terhadap masalah umum dan bagaimana memikirkan pemecahannya. Siswa yang telah termotivasi memiliki keinginan dan harapan untuk berhasil dan apabila mengalami kegagalan mereka akan berusaha keras untuk mencapai keberhasilan itu yang ditunjukkan dalam prestasi belajarnya. Dengan kata lain dengan adanya usaha yang tekun dan terutama didasari adanya motivasi maka seseorang yang belajar akan melahirkan prestasi belajar yang baik.

b. Pengertian belajar

Beberapa pakar mendefenisikan belajar sebagai berikut:

1) Morgan

Belajar adalah perubahan perilaku yang bersifat permanen sebagai hasil dari pengalaman.

2) Harold Spears

Belajar adalah mengamati, membaca, meniru, mencoba sesuatu, mendengar dan mengikuti arab tertentu. 
3) Travers

$$
\text { Belajar adalah proses }
$$

menghasilkan penyesuaian tingkah laku. (Suprijono, 2015:2)

Belajar adalah suatu aktivitas atau suatu proses untuk memperoleh pengetahuan, meningkatkan keterampilan, memperbaiki perilaku, sikap dan mengokohkan kepribadian. Dalam konteks menjadi tahu atau proses memperoleh pengetahuan, menurut pemahaman sains konvensional, kontak manusia dengan alam diistilahkan dengan pengalaman (eksperience). Pengalaman yang terjadi erulang kali melahirkan pengetahuan (knowledge), atau a body of knowledge (Suyono dan Hariyanto, 2012: 9)

Berdasarkan dari uraian di atas, maka dapat disimpulkan bahwa belajar adalah suatu proses usaha yang dilakukan siswa untuk memperoleh suatu perubahan tingkah laku yang baru secara keseluruhan, secara sengaja, disadari dan perubahan tersebut relatif menetap serta membawa pengaruh dan manfaat yang positif bagi siswa dalam berinteraksi dengan lingkungannya.

c. Pengertian motivasi belajar

Menurut (Uno, 2005) motivasi belajar adalah dorongan internal dan eksternal pada pelajar yang sedang belajar untuk mengadakan perubahan tingkah laku, pada umumnya dengan beberapa indikator dan unsur yang mendukung. Indikator motivasi belajar dapat diklasifikasikan sebagai berikut: adanya hasrat dan keinginan berhasil, adanya dorongan dan kebutuhan dalam belajar, adanya harapan dan cita-cita masa depan, adanya penghargaan dalam belajar, adanya kinginan yang menarik dalam belajar, adanya lingkungan belajar yang kondusif (Uno,2005).

Jadi motivasi belajar merupakan motivasi (dorongan) internal dan eksternal siswa untuk belajar guna memperoleh prestasi yang baik.

\section{Pengertian Hasil Belajar}

Hasil belajar adalah pola-pola pembuatan, nilai-nilai, pengertianpengertian, sikap-sikap, apresiasi dan keterampilan. Merujuk pemikiran Gagne (Suprijono, 2015: 5-6), hasil belajar berupa:

(1) Informasi ferbal yaitu kapabilitas mengungkapkan pengetahuan dalam bentuk bahasa, baik lisan maupun tertulis.

(2) Keterampilan intelektual yaitu kemampuan memprsentasikan konsep dan lambing.

(3) Strategi kognitif yaitu kecakapan menyalurkan dan mengarahkan aktifitas kognitifnya sendiri. 
(4) Keterampilan motorik yaitu kemampuan melakukan serangkaian gerak jasmani dalam dalam urusan dan koordinasi.

(5) Sikap adalah kemampuan menerima atau menolak

Menurut Bloom, hasil belajar mencakup kemampuan kognitif, efektif, dan psikomotorik (Suprijono, 2015: 6). Yang harus diingat hasil belajar adalah perubahan perilaku secara keseluruhan bukan hanya salah satu aspek potensi kemanusiaan saja. Artinya, hasil pembelajaran yang dikategorikan oleh para pakar pendidikan sebagaimana tersebut diatas tidak dilihat secara fragmentaris atau terpisah, melainkan komfrehensif.

\section{Pengertian Ilmu Pengetahuan Alam} (IPA)

Pengertian IPA menurut Srini M. Iskandar (1997 : 2) yaitu Ilmu Pengetahuan Alam adalah pengetahuan manusia yang luas yang didapatkan dengan cara observasi dan eksperimen yang sistematis, serta dijelaskan dengan bantuan aturan-aturan, hukum-hukum, prinsip-prinsip, teori-teori dan hipotesa.

Pengertian IPA menurut Maslichah Asy'ari (2006 : 7) sains adalah pengetahuan manuasia tentang alam yang diperoleh dengan cara yang terkontrol. Penjelasan ini mengandung maksud bahwa sains selain menjadi sebagai produk juga sebagai proses. Sains sebagai produk yaitu pengetahuan manusia dan sains sebagai proses yaitu bagaimana mendapatkan pengetahuan tersebut.

Berdasarkan beberapa pendapat ahli di atas maka dapat disimpulkan bahwa pengertian Ilmu Pengetahuan Alam merupakan pengetahuan manusia tentang gejala-gejala alam dan kebebasan yang diperoleh dengan cara observasi, eksperimen/penelitian, atau uji coba yang berdasarkan pada hasil pengetahuan manusia. Pengamatan manusia dapat berupa fakta-fakta, aturan-aturan, hukum-hukum, prinsipprinsip, teori-teori dan lain sebagainya.

\section{METODE PENELITIAN}

Jenis penelitian yang digunakan adalah korelasi. Variabel-variabel dalam penelitian ini sebagai berikut : variabel bebas (independen variabel) yaitu motivasi belajar $(X)$, sedangkan variabel terikat (dependen variabel) adalah hasil belajar (Y) IPA siswa..

Populasi penelitian ini adalah seluruh SDN 231 Inpres Kapunrengan Kecamatan Mangarabombang Kabupaten Takalar. Jumlah murid SD Inpres Bontokanang adalah 174 orang. 
Dalam penelitian ini yang menjadi sampel adalah siswa kelas V SDN 231 Inpres Kapunrengan Kecamatan Mangarabombang Kabupaten Takalar dengan jumlah siswa sebanyak 30 siswa.. Adapun instrumen yang digunakan dalam penelitian ini adalah angket motivasi belajar. Untuk menganalisi data yang diperoleh dari hasil penelitian akan digunakan analisis statistic deskriptif dan analisis korelasi.

\section{HASIL PENELITIAN DAN PEMBAHASAN}

Penelitian ini dilaksanakan di SDN 231 Inpres Kapunrengan Kecamatan Mangarabombang Kabupaten Takalar, terhadap 30 siswa, mengkaji tentang tingkat motivasi belajar terhadap hasil belajar IPA siswa. Data yang diperoleh menggunakan angket untuk mengukur motivasi belajar, dan dokumentasi untuk memperoleh data hasil belajar siswa berupa nilai rata-rata tugas dan ulangan harian.

\section{Analisis Data}

Data yang digunakan dalam penelitian ini yaitu kreativitas guru, motivasi belajar, dan hasil belajar IPA. Sebelum melakukan pengujian terhadap korelasi antar variabel, perlu dilakukan uji normalitas data, karena salah satu syarat penggunaan korelasi Product
Moment Pearson adalah data variabel harus normal. Uji normalitas digunakan untuk melihat seberapa baik sebuah sampel data berada pada distribusi normal.

\section{Uji Normalitas Data}

Uji normalitas menggunakan onesample kolmogrov smirnov (K-SZ) dengan menggunakan SPSS for windows versi 21.0. Syarat suatu data dikatakan berdistribusi normal jika signifikansi atau nilai $\mathrm{p}>0,05$.

Hasil analisis uji normalitas perhatian orang tua dapat dilihat pada tabel 1 berikut:

Tabel 1 Uji Normalitas Data Motivasi

Belajar

One-Sample Kolmogorov-Smirnov Test

\begin{tabular}{|ll|r|}
\hline & & $\begin{array}{r}\text { Motivasi_ } \\
\text { Belalar_X2 }\end{array}$ \\
\hline $\mathrm{N}$ & Mean & 30 \\
Normal & Std. & 40.53 \\
Parameters & Deviation & 4.932 \\
& Devilute & .104 \\
Most Extreme & Absolutive & .089 \\
Differences & Positive & -.104 \\
& Negative & .567 \\
Kolmogorov-Smirnov Z & .905 \\
Asymp. Sig. (2-tailed) &
\end{tabular}

a. Test distribution is Normal.

Jika Asymp.sig> taraf signifikansi 0,05 maka data berdistribusi normal Jika Asymp.sig< taraf signifikansi 0,05 maka data berdistribusi tidak normal 
Dari tabel di atas, nampak bahwa diperoleh mean sebesar 40.53 standar deviasi sebesar 4.93 dan tingkat signifikan (Asymp.sig (2-tailed) adalah 0, 905. Keterangan di bawah tabel "test distribution is normal" menunjukkan bahwa tes tersebut mempunyai data yang normal. Selain itu dari hipotesis yang ada dapat dilihat bahwa Asymp.sig (2-tailed) sebesar 0,905> taraf signifikan 0,05. Karena Asymp.sig (2tailed) lebih besar dari 0,05 (0, $905>$ 0,05) maka Ho diterima yang artinya, variabel motivasi belajar siswa berdistribusi normal.

Hasil analisis uji normalitas hasil belajar ipa siswa dapat dilihat pada tabel 2 berikut:

Tabel 2 Uji Normalitas Data Hasil

Belajar IPA Siswa

\section{One-Sample Kolmogorov-Smirnov Test}

\begin{tabular}{|ll|r|}
\hline & & \multicolumn{1}{|c|}{$\begin{array}{c}\text { Hasil_ } \\
\text { Belajar_Y }\end{array}$} \\
\hline $\mathrm{N}$ & Mean & 30 \\
Normal & Std. & 32.67 \\
Parameters ${ }^{\mathrm{a}, \mathrm{b}}$ & Deviation & \\
& Absolute & .108 \\
Most Extreme & Positive & .104 \\
Differences & Negative & -.108 \\
& Kolmogorov-Smirnov Z & .591 \\
Asymp. Sig. (2-tailed) & .875 \\
\hline
\end{tabular}

a. Test distribution is Normal.

Dari tabel di atas, nampak bahwa diperoleh mean sebesar 82,67 standart deviasi sebesar 3,60 dan tingkat signifikan (Asymp.sig (2-tailed) adalah 0,875 . Keterangan di bawah tabel "test distribution is normal" menunjukkan bahwa tes tersebut mempunyai data yang normal. Selain itu dari hipotesis yang ada dapat dilihat bahwa Asymp.sig (2-tailed) sebesar 0,875> taraf signifikan 0,05. Karena Asymp.sig (2tailed) lebih besar dari 0,05 $(0,875>$ 0,05) maka Ho diterima yang artinya, variabel hasil belajar IPA siswa berdistribusi normal.

\section{Analisis Hasil Penelitian}

Telah dikemukakan pada bagian terdahulu bahwa model analisis korelasi yang digunakan dalam penelitian ini adalah menggunakan analisis korelasi product moment Pearson. Dalam penelitian ini menggunakan dua variabel, yaitu motivasi belajar (x) sebagai variabel independen dengan hasil belajar ipa siswa (y) sebagai variabel dependen. Untuk mengukur eratnya hubungan antara kedua variabel $(x$, dan $y)$ dalam penelitian ini adalah menggunakan analisis korelasi.

Berdasarkan kriteria yang dikemukakan oleh Arikunto (2013:276), 
kriteria yang digunakan sebagai pedoman dalam menafsirkan keeratan hubungan merujuk tolak ukur nilai koefisien korelasi (r) adalah sebagai berikut:

Tabel 3 Interpretasi Koefisien Korelasi (r)

\begin{tabular}{|c|c|}
\hline $\begin{array}{c}\text { Besarnya Nilai } \\
\mathbf{r}\end{array}$ & $\begin{array}{c}\text { Tingkat } \\
\text { Hubungan }\end{array}$ \\
\hline $0,80-1,000$ & Sangat Kuat \\
$0,60-0,799$ & Kuat \\
$0,40-0,599$ & sedang \\
$0,20-0,399$ & Lemah \\
$0,00-1,99$ & Sangat Lemah \\
& (Tidak \\
& berkorelasi) \\
\hline
\end{tabular}

Berpedoman pada kriteria di atas, berikut ini disajikan hasil analisis korelasi antara motivasi belajar terhadap hasil belajar ipa siswa.

\section{Korelasi Motivasi Belajar (X) dengan Hasil Belajar IPA Siswa (Y)}

Tabel 4 berikut ini merangkum data korelasi product moment Pearson antara motivasi belajar dengan hasil belajar ipa siswa.

Tabel 4 Koefisien Korelasi Motivasi

Belajar terhadap Hasil belajar Belajar IPA Siswa

\section{Correlations}

\begin{tabular}{|cl|r|r|}
\hline & & $\begin{array}{r}\text { Motivasi } \\
\text { Belalar (X) }\end{array}$ & \multicolumn{1}{c|}{$\begin{array}{c}\text { Hasil } \\
\text { Belajar (Y) }\end{array}$} \\
\hline & $\begin{array}{l}\text { Pearson } \\
\text { Motivasi }\end{array}$ & 1 & $.449^{*}$ \\
Belalar & $\mathrm{n}$ & & \\
(X2) & Sig. (2- & & .013 \\
& tailed) & & \\
& N & 30 & \\
& Pearson & $.449^{*}$ & \\
Hasil & Correlatio & & \\
Belajar & Sig. (2- & & \\
(Y) & tailed) & & \\
& N & & \\
\hline
\end{tabular}

*. Correlation is significant at the 0.05 level (2-tailed).

Dari tabel 4 nampak koefisien korelasi antara motivasi belajar dengan hasil belajar ipa siswa sebesar 0,449 dan $\rho=0,013$ pada taraf signiifikasi $5 \%$ dan 5\%. Berdasarkan kriteria yang dikemukakan oleh Sugiyono (2010:231), maka koefisien korelasi itu termasuk dalam kategori sedang. Dari data koefisien korelasi ini dapat dijelaskan bahwa motivasi belajar siswa yang tinggi akan diikuti dengan hasil belajar yang tinggi. Sebaliknya motivasi belajar siswa yang rendah akan diikuti dengan hasil belajar yang rendah pula. 


\section{Uji Hasil Hipotesis}

Kriteria penolakan atau penerimaan hipotesis didasarkan pada hasil perhitungan dalam program SPSS for windows versi 21.0 dengan ketenttuan:

1. Menerima Ho dan menolak Ha bila nilai $r_{x y}<0$ dan nilai $p>0,05$. Artinya tidak ada korelasi yang signifikan antara kedua variabel yang dikorelasikan.

2. Menerima Ha dan menolak Ho bila nilai $\mathrm{r}_{\mathrm{xy}}>0$ dan $\mathrm{p}<0,05$. Artinya ada korelasi yang signifikan antara kedua variabel yang dikorelasikan.

Dalam penelitian ini, proses pengelolaan data korelasi dan perhitungan nilai p secara keseluruhan dilakukan dengan bantuan program SPSS for windows versi 21.0.

Hipotesis yang akan diuji dalam penelitian ini adalah:

Ada hubungan yang positif dan signifikan antara motivasi belajar dengan hasil belajar ipa siswa SDN 231 Inpres Kapunrengan Kecamatan Mangarabombang Kabupaten Takalar (Ha: $\beta_{1}>0$ )

Dari hasil analisis diatas menunujukkan variabel motivasi belajar berkorelasi positif signifikan dengan hasil belajar ipa siswa $(r=0,449)$, dengan $p=0,013$. Karena $0,449>0$ dan $\mathrm{p}=0,013<0,05$ (Ha: $\left.\beta_{1}>0\right)$ Ha diterima dan Ho ditolak.

Hasilnya bahwa hipotesis yang menyatakan "tidak ada hubungan positif dan signifikan antara motivasi belajar dengan hasil belajar ipa siswa SDN 231 Inpres Kapunrengan Kecamatan Mangarabombang Kabupaten Takalar ditolak, dan diterima hipotesis "ada hubungan positif dan signifikan antara motivasi belajar dengan hasil belajar ipa siswa SDN 231 Inpres Kapunrengan Kecamatan Mangarabombang Kabupaten Takalar".

\section{KESIMPULAN}

Berdasarkan hasil penelitian yang telah diuraikan, dapat diambil kesimpulan sebagai berikut, Ada hubungan positif dan signifikan antara motivasi belajar terhadap hasil belajar IPA siswa kelas V SDN 231 Inpres Kapunrengan Kecamatan Mangarabombang Kabupaten Takalar, dengan koefisien korelasi sebesar 0,449 dan $\mathrm{p}=0,013$.

Mengingat pentingnya faktorfaktor motivasi belajar untuk meningkatkan hasil belajar siswa, maka (1) Siswa hendaknya lebih meningkatkan hasil belajar yang dilaksanakan oleh sekolah serta dapat meningkatkan penguasaan materi pelajaran, dan keterampilan- 
keterampilan dalam memecahkan masalah, jangan mudah putus asa untuk mencapai cita-cita di masa depan. (2) Pihak sekolah agar melengkapi sarana prasarana bimbingan konseling, bekrjasama dengan instansi lain, misalnya dalam alih tangan kasus kepada yang lebih profesional dalam penanganan-penanganan lebih lanjut.

\section{DAFTAR PUSTAKA}

Arikunto, Suharsimi. 2003. Manajemen Penelitian. Jakarta: Rineka Cipta.

Arikunto, Suharsimi. 2006. Prosedur Penelitian Suatu Pendekatan Praktik. Jakarta: Rineka Cipta.

Dimyati dan Mudjiono. 2013. Belajar dan Pembelajaran. Jakarta. Rineka Cipta.

E. Mulyasa, 2013. Menjadi Guru Profesional Menciptakan Pembelajaran Kreatif dan Menyenangkan, Bandung: PT. Rosdakarya.

http// www. Kajian teori. Com/2013/03/teori-iapengertian-ilmu-pengetahuanalam-ipa.html. diakses 3 maret 2013.
Munandar, Utami. 2014. Pengembangan Kreativitas Anak Berbakat. Jakarta: Rineka Cipta.

Rusman. 2013. Seri Manajemen Sekolah Bermutu (Model - Model Pengajaran) Mengembangkan Profesionalisme Guru. Jakarta: PT. Raja Grafindo Persada.

Santrock, John W. 2007. Psikologi Pendidikan.Jakarta: Kencana Prenada Media Group.

Sardiman. 2006. Interaksi dan Motivasi Belajar Mengajar. Jakarta: PT. Raja Grafindo Persada.

Sugiyono. 2010. Statistika untuk Penelitian. Bandung: Alfabeta.

Sugiyono. 2013. Metode Penelitian Pendidikan Pendekatan Kuantitatif, Kualitatif, dan $R \& D$. Bandung: Alfabeta.

Suprijono, Agus. 2015, Cooperative Learning, Yogyakarta: Pustaka Pelajar

Suyono dan Hariyanto. 2012. Belajar dan Pembelajaran. Bandung: PT Remaja Rosdakarya.

Uno, Hamzah B. 2008. Orientasi Baru dalam Psikologi Pendidikan. Jakarta: PT Bumi Aksara. 